\title{
SOSIAL EKONOMI ATLET DAYUNG KALIMANTAN TENGAH
}

\author{
U. Z. Mikdar' ${ }^{1}$, Roso Sugiyanto ${ }^{2}$ \\ ${ }^{1}$ Jurusan Pendidikan Jasmani, Kesehatan, dan Rekreasi, FKIP Universitas Palangka Raya \\ ${ }^{2}$ Program Studi PGSD, FKIP Universitas Palangka Raya \\ Jln. Hendrik Timang, Kampus Tunjung Nyaho UPR, Palangka Raya, Kalimantan Tengah \\ 1e-mail: mikdar@fkip.upr.ac.id
}

\begin{abstract}
Abstrak
Komite Olahraga Nasional Indonesia (KONI) Kalimantan Tengah tugasnya adalah membina olahraga prestasi, salah satunya adalah cabang olahraga dayung yang bermedali di setiap Pekan Olahraga Nasional (PON), dan penyumbang atlet dan pelatih nasional. Tujuan penelitian ini untuk mendeskripsikan sosial ekonomi mantan atlet dayung nasional Kalimantan Tengah. Penelitian ini termasuk penelitian kualitatif deskriptif dengan subyek/informannya adalah mantan atlet dayung nasional asal Kalimantan Tengah. Hasil penelitian ini menunjukkan bahwa (1) alasan menjadi atlet karena: (a) sejak kecil, sudah terbiasa berolahrga, tinggal di lingkungan dan budaya sungai; (b) bersekolah di lembaga keolahragaan; dan (c) terinspirasi oleh atlet nasional. Dampak lainnya, selama menjadi atlet nasional terkadang sekolah atau pekerjaan dan keluarga terganggu bila ada event nasional maupun internasional; (2) Pencapaian prestasi yang diraih, yaitu pada tingkat nasional, Asia Tenggara, Asia, juga internasional; dan (3) nilai sosial ekonomi yang didapatkan: (a) menjadi Aparatur Sipil Negara (ASN); (b) mendapatkan bonus uang; (c) nendapatkan hibah kavling tanah; (d) mendapatkan hadiah rumah; (e) kemudahan memilih sekolah; (f) bisa beribadah haji; dan (g) bisa jalan-jalan ke luar negeri.
\end{abstract}

Kata kunci: sosial ekonomi, atlet, dayung

\begin{abstract}
The Central Kalimantan KONI in its task is to guide achievement sports, one of them is rowing. It succeeds in getting medals in PON events. It contributes athletes and national coaches at International events. This study aims to describe the social economic aspects of Central Kalimantan rowing athletes. This research is a descriptive qualitative research with the subjects are formers of national rowing athletes from Central Kalimantan. The results of this study indicate that (1) the reasons for being athletes are because: (a) since childhood they used to exercise, live in the environment and culture of the river; $(b)$ attend a sports institution; $(c)$ inspired by national athletes. Other impacts, while being national athletes, school, work or family transferred them in national or international events; (2) Achievement achieved in national, Southeast Asia, Asia, and also internationa events; (3) the economic values (a) becoming a civil servant (ASN); (b) a cash bonus; (c) a land grant; (d) a house; (e) the convenience of choosing a school; $(f)$ pilgrimage to Mecca; and ( $g$ ) travelling abroad.
\end{abstract}

Keywords: social ekonomic, athletes, rowing

\section{PENDAHULUAN}

UU Nomor 3 Tahun 2005 tentang Sistem Keolahragaan Nasional (SKN).

Pasal 39 menyebutkan, bahwa tugas KONI Provinsi dan Kabupaten/Kota antara 
lain mengkoordinasikan induk organisasi cabang olahraga (Cabor) dan organisasi olahraga fungsional dan menyiapkan, melaksanakan, serta mengkoordinasikan keikutsertaan cabang olahraga prestasi dalam kegiatan olahraga yang bersifat lintas daerah dan nasional.

Komite Olahraga Nasional (KONI) Kalimantan Tengah dalam tugasnya, membina sebanyak 36 cabang olahraga prestasi yang menjadi anggota KONI Kalimantan Tengah, salah satunya adalah cabang olahraga dayung yang menjadi unggulan utama Kalimantan Tengah dan penyumbang medali di setiap Pekan Olahraga Nasional (PON). Selain itu, juga selalu menjadi daerah yang menyumbang atlet dan pelatih nasional pada event dayung Internasional. Keberhasilan seseorang menjadi atlet nasional tentunya tidak akan terlepas dari berbagai aspek yang mempengaruhinya, baik aspek kepribadian, motivasi berpresatsi dari atlet itu sendiri, kemauan, kesungguhan, semangat, kesehatan, dan juga faktor lingkungan social lainnya, seperti tempat tinggal, keluarga, pendidikan, dan faktor sosial budaya dan lainnya.

Hal ini sejalan dengan yang diungkapkan Mc Clelland (Anwar, 2005) mengemukakan 6 karakteristik orang yang mempunyai motivasi berprestasi tinggi, yaitu (1) memiliki tingkat tanggung jawab pribadi yang tinggi, (2) berani mengambil dan memikul risiko, (3) memiliki tujuan realistik, (4) memiliki rencana kerja yang menyeluruh dan berjuang untuk merealisasikan tujuan, (5) memanfaatkan umpan balik yang konkrit dalam semua kegiatan yang dilakukan, dan (6) mencari kesempatan untuk merealisasikan rencana yang telah diprogramkan. Mc.Clelland's Achievment Motivation Theory atau teori motivasi prestasi (Robbins, 2001) mengemukakan bahwa individu mempunyai cadangan energi potensial, bagaimana energi ini dilepaskan dan dikembangkan tergantung pada kekuatan atau dorongan motivasi individu dan situasi serta peluang yang tersedia.

Kaitannya dengan motivasi berpresatasi seorang atlet, seperti yang telah ditunjukan oleh Zohri peraih medali emas dalam lomba lari 100 meter pada kejuaraan dunia atletik U-20 beberapa tahun lalau. Secara sosial ekonomi, bisa merubah hidupanya dari warga relatif "miskin" menjadi warga yang kaya raya 
setelah mendapatkan berbagai hadiah, baik yang berbentuk uang, jasa bahkan aset. Seperti dari Kemenpora mendapatkan 250 juta, Pemda NTB 200 juta, Kemendagri hadiah rumah senilai 750 juta, Metro TV 100 juta, Hotman Paris 100 juta, pegadaian $1 \mathrm{~kg}$ emas (bila diuangkan sekitar 500 juta), Aksi Cepat Tanggap (ACT) uang tunai 25 juta dan aset minimarket Sodaqo 300 juta, bila ditotalkan 2,23 Miliar, belum termasuk hadiah-hadiah lainnya.

Fakta empirik tersebut, menjadi bagian alasan yang dapat memperkuat penelitian ini, setidaknya yang terkait dengan sosial ekonomi atlet dayung nasional yang ada di Kalimantan Tengah, diantaranya mulai dari (1) alasan menjadi atlet, (2) pencapaian prestasi yang pernah diraih, dan (3) nilai-nilai ekonomi yang didapatkan selama menjadi atlet. Pemecahan masalah yang dilakukan untuk menggali dan mendapatkan informasi untuk penelitian ini dengan cara melakukan terjun langsung ke lapangan dengan mendatangi mantan atlet nasional asal di Kalimantan Tengah dengan cara wawancara dan penelusuran dokumen prestasi.

Dengan beberapa alasan tersebut, maka penelitian ini bertujuan untuk mengkaji dan mengungkap permasalahan dari sosial ekonomi atlet dayung nasional asal Kalimantan Tengah, baik mulai dari aspek (1) alasan menjadi atlet, (2) pencapaian prestasi yang pernah diraih, dan (3) nilai-nilai sosial ekonomi yang didapatkan selama menjadi atlet. Manfaat dari penelitian ini secara teoris untuk memperkuat teori kebutuhan dasar manusia dari Maslow (2010) dan teori serta konsep olahraga prestasi. Sedangkan manfaat secara praktis, sekurang-kurangnya untuk (1) memberi informasi ilmiah tentang nilai-nilai olahraga prestasi, (2) merangsang masyarakat khususnya generasi muda Indonesia untuk menekuni olahraga prestasi, dan (3) memberikan informasi awal untuk mengkaji lanjut secara komprehensif tentang nilai-nilai olahraga khususnya olahraga prestasi.

\section{METODE}

Penelitian ini termasuk jenis penelitian kualitatif deskriptif dengan bentuk survey dan wawancara yang menggambarkan perilaku, pemikiran, atau perasaan suatu kelompok atau individu. Informan dari penelitian ini adalah mantan atlet 
dayung nasional Indonesia asal Kalimantan Tengah, yang telah mengikuti berbagai kejuraan pada level internasional. Penentuan sumber data adalah pada orang atau mantan atlet dayung nasional asal Kalimantan Tengah yang diwawancarai dan dilakukan secara purposive juga menggunakan Snowball sampling yaitu dipilih dengan pertimbangan dan tujuan tertentu. Hasil penelitian ini tidak akan digeneralisasikan ke populasi karena, pengambilan sampel tidak diambil secara random. Teknik pengumpulan data melalui wawancara dan pengamatan harian, yang melibatkan 13 informan sebagai mantan atlet dayung nasional. Teknik analisis data dalam penelitian ini, dilakukan setelah data-data diperoleh melalui teknik wawancara mendalam dan observasi. lalu dikonfirmasikan dengan informan secara terus menerus secara triangulasi.. Artinya, peneliti mengadakan pengulangan untuk mendatangi informan dan wawancara kaitannya dengan penguatan dan penegasan kembali informasi data dan detil prestasi yang pernah dicapai, serta sumber reward yang didapatkan setelah sukses menjadi atlet nasional.

\section{HASIL DAN PEMBAHASAN}

Beberapa temuan dari penelitian yang terkait dengan sosial ekonomi mulai alasan menjadi atlet, prestasi yang pernah dicapai dan nilai-nilai ekonomi yang didapatkan, adalah sebagai berikut:

\section{Alasan Menjadi Atlet}

Diantara hasil wawancara dengan beberapa mantan atlet nasional menyatakan "sebelum menjadi atlet dayung, awalnya hanya menyenangi olahraga bulutangkis, karena terinspirasi oleh Hartono yang menjuarai kejuaraan All England 8 kali. Bahkan juga sejak SMP sudah senang olahraga atletik, balap sepeda, bahkan juara, namun sempat kecewa tidak pernah berangkat (ke Jakarta) mengikuti kejuaraan. Akhirnya pada tahun 1980-1981 mendatangi KONI mencari informasi prioritas pembinaan olaharga di KONI, ternyata dayung menjadi prioritas pembinaan pada saat itu. Informan lain menyatakan bahwa sejak di kampung sudah terbiasa ikut lomba dayung, misalnya pada kegiatan acara Agustus yang merupakan tradisi kampung. Disamping itu, sering kali melihat 
temannya sering ke luar negeri ikut kejuaraan dayung, serta saran orang tua untuk sekolah di SGON supaya bisa cepat kerja sebagai guru olahraga.

Alasan memilih cabang olahraga dayung, karena cabang olahraga dayung adalah cabang olahraga primadona Kalimantan Tengah, karena pada saat itu ada dana abadi dari Pemerintah Daerah, yang pada saat itu, juga lagi hangat-hangatnya dukungan pendanaan, yang dikenal dengan dukungan dari "SDSB dan PORKAS" juga dukungan perusahaan HPH (Hak Penguasaan Hutan).

Paparan informan tersebut, membuktikan dan menjadi alasa menjadi atlet dayung nasional, yang secara rinci karena, (1) sejak kecil sudah terbiasa tinggal di lingkungan dan dekat dengan sungai yang mempengaruhi perilaku sosial dan gerak dalam olahraga, (2) terbiasa dengan perilaku dan budaya gerak olahraga seperti mendayung dan berenang, (3) bersekolah di lembaga keolahragaan, pada saat itu menjadi siswa SMOA (Sekolah Menengah Olahraga Atas), (4) sejak kecil sudah terbiasa berolahraga; (5) terbiasa ikut-ikutan berlatih olahraga, dan (5) terinspirasi oleh atlet nasional yang sering ke luar negeri, juga sering melihat figur atlet kelas dunia seperti atlet bulutangkis Hartono.

Fakta tersebut membuktikan hasil penelitian dari Rogers (1974) yang dikutif oleh Paradhita (2011), yang mengungkapkan bahwa sebelum orang mengadopsi perilaku baru (berperilaku baru), di dalam diri orang tersebut terjadi proses yang berurutan, yakni (1) awareness (kesadaran), yakni orang tersebut menyadari dalam arti mengetahui setimulus (objek) terlebih dahulu, (2) interest, yakni orang mulai tertarik kepada stimulus, (3) evaluation (menimbang-nimbang baik dan tidaknya stimulus bagi dirinya), (4) trial, orang telah mulai mencoba perilaku baru, dan (5) adoption, subjek telah berperilaku baru sesuai dengan pengetahuan, kesadaran, dan sikapnya terhadap stimulus.

Oleh karenanya, lingkungan adalah salah satu faktor yang mempengaruhi terhadap pembentukan dan perkembangan perilaku individu, baik lingkungan fisik maupun lingkungan sosio-psikologis, termasuk di dalamnya adalah belajar dan pelatihan olahraga. Lingkungan juga terkadang sering disebut patokan utama pembentukan prilaku. Semuanya dikaitkan dengan lingkungan dan manusia pun selalu tergantung pada lingkungannya. Terhadap faktor lingkungan ini ada pula 
yang menyebutnya sebagai empirik yang berarti pengalaman, karena dengan lingkungan itu individu mulai mengalami dan mengecap alam sekitarnya. Manusia tidak bisa melepaskan diri secara mutlak dari pengaruh lingkungan itu, karena lingkungan itu senantiasa tersedia di sekitarnya.

Makanya, yang menjadi alasan sehingga menjadi atlet nasional karena faktor lingkungan, serta tempat tinggal keseharin yang sama mempengaruhinya. Fakta membuktikan bahwa berprestasi dayung pada level nasional karena (1) terbiasa tinggal di lingkungan dan dekat dengan sungai yang mempengaruhi perilaku sosial dan budaya gerak olahraga dayung, (2) bersekolah di lembaga keolahragaan, mempengaruhi kekuataan dan jiwa kerolaahragaan, dan (3) sejak kecil sudah terbiasa berolahraga dan ikut-ikutan berlatih olahraga.

\section{Prestasi yang Pernah Diraih}

Beberapa temuan dari hasil wawancara dengan beberapa informan, bahwa event yang pernah diikuti diantaranya adalah Pra Kualifikasi Dunia Slalom dan Arung Jeram di Jerman; di Coa Ting Prestasi tertinggi di Cina/Hongkong di nomor Racing dengan Ramli dari Sulsel, Sea Games Singapore, Asean Grand Prik Thailand, Asean Games, dan beberapa even lainnya.

Beberapa prestasi yang pernah diraih oleh atlet dayung nasional Indonesia asal Kalimantan Tengah adalah selain berprestasi di tingkat nasional, juga berprestasi pada level internasional, bahkan mengikuti berbagai even dan pertandingan dan berprestasi di beberapa negara Asia, Australia dan Eropa, juga menjuarai level Sea Games, Asia, dan event internasional lainnya. Temuan lainnya, adalah selama menjadi atlet nasional terkadang sekolah atau pekerjaan dan keluarga terganggu bila harus melakukan pemusatan latihan dan pertandingan ke luar negeri.

Teori yang mendukung temuan dalam penelitian ini adalah teori dan pandangan Homans (1974) mengenai teori pertukaran sosial, Homans memperkenalkan sekumpulan proposisi fundamental, yaitu: sukses, stimulus, nilai, deprivasi-kejemuan (deprivasi-satiasi), dan restu-agresi atau approval aggression. Proposisi sukses menyatakan bahwa "untuk semua tindakan yang dilakukan seseorang, semakin sering tindakan khusus seseorang diberi hadiah, 
semakin sering kemungkinan orang melakukan tindakan itu". Artinya dengan mengikuti berbagai even dunia dan mewakili Indonesia pada event dunia seperti pertandingan di beberapa negara Asia, Australia dan Eropa, juga menjuarai level Sea Games, Asia, internasional lainnya, memberi bukti adanya rangsangan dan stimulus, bahkan menjadi penghargaan, harkat martabat terhadap dirinya, orang tua, masyarakat, dan lingkungannya termasuk secara finasial. Oleh karenanya berpengaruh dan termotivasi untuk berlatih kembali dengan sungguh-sungguh untuk berprestasi dalam kegiatan olahraga.

Sedangkan proposisi nilai menyatakan bahwa "makin tinggi nilai hasil tindakan seseorang bagi dirinya, makin besar kemungkinan ia melakukan tindakan itu, artinya semakin sering dipercaya untuk mewakili Indonesia pada event-event dunia dan lainnya, maka atlet nasional asal Kalimantan Tengah merasa bermanfaat untuk dirinya, bahkan semakin termotivasi untuk aktif dalam kegiatan olahraga yang dikembangkannya. Berdasarkan alasan tersebut, dapat dikatakan bahwa pertukaran sosial menurut Homans (1974) adalah kurang lebih sebagai pertukaran hadiah (reward) atau biaya (cost) antara dua orang atau lebih.

\section{Nilai Sosial Ekonomi}

Hasil wawancara dengan beberapa atlet nasional dayung Kalimantan Tengah yang menyatakan beberapa hal yang didapatkan dari dayung itu, adalah bahwa pada saat itu dirinya mendapatkan bonus berupa uang dari Pusat (KONI) 2,5 juta KONI (Pemprov) 3 juta, Tahun 1993 dapat medali emas Kano Asia dapat bonus 18 juta, tahun 19968 juta, 200450 juta dari dinas PU, KONI, dan Pemerintah Kabupaten. Sedangkan tahun 200840 juta, tahun 2012260 juta, bahkan dipakai ibadah naik haji.

Selain itu, dengan berprestasi di dayung juga bisa diangkat menjadi Aparatur Sipil Negra (ASN), bahkan bisa membeli rumah.Temuan lainnya adalah atlet dayung yang berprestasi nasional, saat ini bisa menjadi pimpinan Cabang BPK (Bank Pembangunn Kaliamantan Tengah), yang sebelumnya diangkat hanya sebagai security saja. Temuan dari beberapa informan itu, umumnya mereka mendapatkan bonus berupa uang, dan menjadi ASN, serta fasilitas lainnya dari Gubernur dan pemerintah daerah setempat. 
Sangat jelas dari ungkapan para mantan atlet nasional Kalimantan Tengah tersebut, ada sejumlah nilai-nilai ekonomi yang didapatkan, diantaranya adalah (1) menjadi Aparatur Sipil Negara (ASN); (2) mendapatkan bonus uang; (3) mendapatkan kavling tanah; (4) mendapatkan rumah; (5) failitas dan kemudahan masuk sekolah; (6) bisa ibadah haji ke Mekkah; dan (7) bisa traveling ke luar negeri.

Bahkan diantaranya sebagian bisa menjadi pejabatan pemerintah termasuk pejabat di BUMD Provinsi. Sedangkan beberapa lembaga yang memberikan reward, adalah (a) Presiden; (b) Gubernur (Pemerintah Provinsi), (c) Bupati/Walikota (Pemerintah Kabupaten/Kota), (d) Menteri Pemuda dan Olahraga, (e) Kementerian Pendidikan dan Kebudayaan, (f) KONI Pusat, (g) Pengurus Pusat (PP) Cabang Olahraga, (h) Pengurus Provinsi Cabang Olahraga (PENGPROV), dan (i) masyarakat.

Temuan-temuan tersebut, juga bisa menjadi bukti dukungan teori dan Homans (1974) mengenai teori pertukaran sosial, Homans memperkenalkan sekumpulan proposisi fundamental, yaitu: sukses, stimulus, nilai, deprivasikejemuan (deprivasi-satiasi), dan restu-agresi atau approval aggression. Proposisi sukses menyatakan bahwa "untuk semua tindakan yang dilakukan seseorang, semakin sering tindakan khusus seseorang diberi hadiah, semakin sering kemungkinan orang melakukan tindakan itu". Artinya dengan mengikuti berbagai even dunia dan mewakili Indonesia pada event dunia seperti pertandingan di beberapa negara Asia, Australia dan Eropa, juga menjuarai level Sea Games, Asia, internasional lainnya, memberi bukti adanya rangsangan dan stimulus untuk berlatih olahraga.

Sedangkan proposisi nilai menyatakan bahwa "makin tinggi nilai hasil tindakan seseorang bagi dirinya, makin besar kemungkinan ia melakukan tindakan itu, artinya semakin sering dipercaya untuk mewakili Indonesia pada event-event dunia dan lainnya, maka atlet nasional asal Kalimantan Tengah merasa bermanfaat untuk dirinya, bahkan semakin termotivasi untuk aktif dalam kegiatan aktifitas olahraga yang dikembangkannya. 
Keadaan tersebut, diperkuat oleh teori kebutuhan dasar manusia dari Maslow (2010) diantaranya kebutuhan akan "penghargaan” seperti status sosial, prestasi, penghormatan dari orang lain, nama baik, reputasi, ketenaran, perhatian, dan lain-lain. Oleh karena itu, atlet yang berprestasi baik ditingkat nasional, internasional, maka akan merasa dihargai dirinya, keluargannya dari lingkungan sekitarnya. Dengan pencapaian akan "penghargaan" tersebut bisa mendorong untuk mencapai pada tingkat kebutuhan yang lebih tinggi akan kebutuhan aktualissai diri. Oleh karenanya, atlet-atlet dayung tersebut akan semakin termotivasi untuk melakukan dan berlatih olahraga, baik pada level nasional bahkan internasional. Maslow (2010) memandangnya bahwa kebutuhan akan aktualisasi merupakan dorongan keinginan yang timbul secara terus menerus, dan dorongan ini akhirnya berubah menjadi potensi yang sangat dahsyat bagi atlet nasional tersebut. Maslow (2010) mengatakan bahwa kebutuhan ini ada di dalam diri seseorang dengan cara mendorong diri sendiri untuk bertindak sesuai dengan yang dikehendaki.

\section{SIMPULAN}

Kesimpulan dari penelitian ini adalah bahwa sosial ekonomi mantan atlet dayung nasional Kalimantan Tengah, dengan rincian sebagai berikut. (1) Alasan menjadi atlet karena: (a) sejak kecil sudah terbiasa berolahraga, tinggal di lingkungan dan budaya sungai; (b) bersekolah di lembaga keolahragaan; (e) terinspirasi oleh atlet nasional. (2) Dampak lainnya selama menjadi atlet nasional terkadang sekolah atau pekerjaan dan keluarga terganggu bila ada event nasional maupun internasional. (3) Pencapaian prestasi yang diraih, selain meraih prestasi nasional, juga berprestasi pada level Asia Tenggara, Asia, juga Internasional lainnya. (4) Nilai ekonomi yang didapatkan sebagai atlet nasional adalah (a) menjadi aparatur sipil negara (ASN); (b) mendapatkan bonus berupa uang; (c) mendapatkan hibah kavling tanah; (d) mendapatkan rumah; (e) diberikan kemudahan memilih sekolah; (f) bisa beribadah naik haji; dan (g) bisa traveling ke luar negeri. 


\section{DAFTAR PUSTAKA}

Maslow, A., H. (2010). Motivation and personality. Rajawali, Jakarta.

Anwar, P., M. (2005). Evaluasi kinerja SDM. Bandung: PT. Refika Aditama.

Bungin, B. (2008). Analisis data penelitian kualitatif. Jakarta: PT. Raja Grafindo Persada.

Bisnis.Com. (Online), (https://sport.bisnis.com/read/20180727/59/821448/gajiatlet-dan-persiapan-masa-pensiun, diakses 28 Mei 2020)

Paradhita, D., R. (2011). Pengaruh lingkungan terhadap prilaku individu. (Online),(https://a62747.wordpress.com/2011/02/23/pengaruh-lingkunganterhadap-prilaku-individu/, dikases 18 Mei 2018).

Haag, H. (1994). Theoretical foundation of sport science as a scientific discipline: contribution to a philosophy (meta-theory) of sport science. Schourdorf: Verlaag Karl Hoffmann.

Homans, G., C. Elementary form of social behavior. $2^{\text {nd }}$ edition. New York: Harcourt Brace Jovanovich,1974. Sebagaimana dikutip dalam https://www.d.umn.edu/cla/faculty/jhamlin/4111/Exchange/HomansReadi ng1.html.

Jurnal Manajemen.com. (2019). Teori Kebutuhan Maslow Dan Contohnya Pada Perusahaan. (Online), (https://jurnalmanajemen.com/teori-hierarkikebutuhan-maslow/, diakses 26 Juli 2019).

Moeleong, L., J. (2002). Metodologi penelitian kualitatif. Bandung: Remaja Rosdakarya.

Schacht, R. (1998). Nietzsche and sport. International Studies and Philosophy. 30(6), 123-130.

Robbins, S., P. (2001). Psikologi organisasi, Edisi ke-8. Jakarta: Prenhallindo.

Sugiyono. (2009). Metode penelitian kuantitatif, kualitatif dan $R \& D$. Jakarta: Alfabeta.

Sunardianta, R., dkk. Pergeseran fungsi olahraga dalam dimensi sosial. (Online) (http://staff.uny.ac.id/sites/default/files/penelitian/dr-muhammad-hamidanwar-m-phil/pergeseran-fungsi-olahraga.pdf, diakses 6 Agustus 2019). 